\title{
TOTAL QUALITY ZERO WASTE MANAGEMENT SYSTEM
}

\author{
Jan Vincent S Saracanlao ${ }^{1}$ \\ Lorejo Juliet E. ${ }^{2}$ \\ Evangelista Linden $\mathrm{L}^{3}$. \\ Lim Love C. ${ }^{4}$ \\ Naelga Sofia $C^{5}$
}

Abstract: Framed by Total Quality

Management Principles derived from the ISO 9001:2000 standard, The Total Quality Zero

Waste Management System is macro research managing (4) four micro researches using Principle of Total Quality Management. The entire researches sought to address the solid waste in Misamis Oriental General Comprehensive High School. The system begins with (Lorejo et al) entitled Micro-Segregation System: Redesigning Traditional Garbage Bins for Specificity, Purpose and Functionality. It aimed to restructure the traditional paradigm of waste segregation bins and its design. The next phase was on micro waste processing system. Each bins and type of waste were distributed to different solid waste processing facilities.
The paper type (paper and paper cups) is framed by the research of (Permites et al) entitled Paper Type Waste Treatment Facility: Processing Paper Type Waste in MOGCHS to other Potential Outcomes. Similar to this is the study of (Lim et al) Leaves and Perishable Waste Treatment Facility: Processing leaves and Perishable Waste in MOGCHS for Composting Organic Fertilizer. Another researches from (Ranalan et al) entitled Endothermic Construction material made from recycled plastic bottles fused with ethylene Glycol. These sub researches are managed by this main research Total Quality Zero Waste Management System. The study sought to answer the following questions 1 . What is the evaluation of degree of application of each Total Quality

\footnotetext{
${ }^{1}$ Department of Education

${ }^{2}$ Division of Misamis Oriental

${ }^{3}$ Division of Misamis Oriental

${ }^{4}$ Division of Misamis Oriental

${ }^{5}$ Division of Misamis Oriental
} 


\section{Sitainero}

Periódico do Núcleo de Estudos e Pesquisas sobre Gênero e Direito Centro de Ciências Jurídicas - Universidade Federal da Paraíba V. 8 - $\mathrm{N}^{\circ} 07$ - Ano 2019 - Special Edition ISSN | 2179-7137 | http://periodicos.ufpb.br/ojs2/index.php/ged/index

Management Principles derived from the ISO 9001:2000 standard in the project management of the Total Quality Zero Waste Management System 2. What is the evaluation of the sub researchers toward the head researchers application and use of Total Quality Management Principles derived from the ISO 9001:2000 standard. The study found out that the principles in Total Quality Management was an effective management model as used in project management and delivery. Specifically, the researches met and tried to go beyond the standard set by Local Ordinance No. 13130-2016 is in line with Section 166 of Republic Act 9003, the Ecological Solid Waste Management Act of 2000. Leadership demands were carried out through weekly meeting. During these times purpose, direction and other content that needs to be communicated were delivered. Students and teachers were involved in the project. They were also oriented on the project and how they can participate and make contribution for the success of the project. PDCA (PLAN, DO, CHECK and ACT) tool kit was used in the study. Total Quality Zero Waste Management System follows a system approach. Each different research is a part of the whole which is this research. Each research is i ndependent from other research, however there is a consequential connection between each research to the other. The results of the research of each researcher influence the other research. Total Quality Zero Waste Management System has a bottom up feedback/evaluation mechanism. This research and each researches made use of statistical procedure to evaluate the implementation of the program, the innovation and the facility. Descriptive statistics, percentage, frequency and frequency distribution, mean and standard deviation were used in the study. All of these statistical results were used to evaluate and present the project, and the processes within the project. The statistical results were also used as basis for future improvements. In some cases, immediate but minor augmentation and corrective procedure of the facility, program and processes within the project to ensure quality implementation and delivery of the system. Communicating a shared value of quality to the suppliers of the facilities, the users of the facilities and the contributors of the project was one of the most challenging endeavor that this research encountered. It was already a challenge 


\section{S5ireinere}

Periódico do Núcleo de Estudos e Pesquisas sobre Gênero e Direito Centro de Ciências Jurídicas - Universidade Federal da Paraíba V. 8 - No 07 - Ano 2019 - Special Edition ISSN | 2179-7137 | http://periodicos.ufpb.br/ojs2/index.php/ged/index

imparting and owning that shared value of quality amongst researchers, much more sharing, communicating, imparting and owning that value to others. It is recommended to use Total Quality Management Principles as framework for the development and delivery of a project. It is recommended that each institution, private or government, local or national to adopt and implement the Total Quality Zero Waste Management System with its corresponding facility.

Keywords: Total Quality Management, Zero Waste Management, Segregation

\section{Introduction}

In an online article entitled Strict Implementation of Waste Segregation, Change.org (2019) it was mentioned that the global community is aware that Solid Waste Management is an issue that needs serious attention. Developing countries like the Philippines aggressive pursuit for economic growth has resulted in the manufacture, distribution and use of products. This consequentially results in the generation of wastes that contributes to destruction environmental and global climate change. Frequent and intense floods the country is a result of the destruction of the environment. The country experiences devastating typhoons which may be due to climate change due to excessive and improper waste processing and disposal.

Poor solid waste management in the Philippines is still prevalent despite government efforts. In addition open and controlled dumps in the country poses great threats on the country's environment and public health.

The concept of poor solid waste management is raised in a national-wide practice. This can be elucidated in this scenario. There are currently three (3) recycle bins. Biodegradable, Non-biodegradable and recyclable. The concept itself is confusing, considering that people don't have the time to discern or take time to discern when throwing waste. It is then all futile because even after the thorough segregation of Biodegradable, Non-biodegradable and recyclable it is then collected by one garbage truck that basically place everything together.

If collected separately, the current practices of segregating recyclables, nonrecyclables and bio-degradable will eventually go through another process of separating paper, plastic, metal, leaves and 


\section{Sitainero}

Periódico do Núcleo de Estudos e Pesquisas sobre Gênero e Direito

Centro de Ciências Jurídicas - Universidade Federal da Paraíba

V. 8 - No 07 - Ano 2019 - Special Edition ISSN | 2179-7137 | http://periodicos.ufpb.br/ojs2/index.php/ged/index

perishables after segregation if treatment is pursued. Thus, it is inevitable to segregate the three types of recyclables so that it will go directly to the process of treatment.

The micro-segregation system, challenges the paradigm of traditional recyclables, non-recyclables and biodegradable embodying three relevant concept of Specificity, Purpose and Functionality. This research proposes that there should be 5 (five) bins, fabricated from size 4 PVC pipes to serve as micro bins. The five (5) bins have specific function and role. One bin is for paper type (paper, paper cups, paper board). Second bin is for plastic type (Polyethylene, polypropylene, plastic cups, cellophanes). Third bin is for leaves and biodegradable including food scraps. Fourth, is for foil type wrappers, candy wrappers and the likes. The fifth bin is for direct trash, this may include feminine pads, broken glass, and the likes.

Notice, that there are no bins for metals, glasses, and containers, simply because as a school those types of waste are very rare. And it has direct sales, usually directly sold to junk shops. As a school and as the venue for this research those type of waste are very minimal. If it does exist, it can either be sold directly to junk shops or it can be gathered by the school dump truck.

The challenge is providing a management model to facilitate zero-waste in MOGCHS. Thus, the main research is formulated.

\section{Methods}

Mixed methods were used in the study. Mixed methods combine qualitative and quantitative methods in ways that evidently bridge their differences in addressing a research question.

Creswell (2003) described six somewhat overlapping mixed methods research designs, referred to as strategies of inquiry, that guide the construction of specific features of a mixed methods study. The second mixed methods approach as used in the study is the sequential exploratory design, is essentially the reverse of the sequential explanatory design, with quantitative data used to enhance and complement qualitative results. This approach is especially useful when the researcher's interest is in enhancing generalizability, and it may or may not be guided by a theoretical perspective. The quantitative results are then used to enhance, 


\section{SôtGinere}

Periódico do Núcleo de Estudos e Pesquisas sobre Gênero e Direito

Centro de Ciências Jurídicas - Universidade Federal da Paraíba

V. 8 - No 07 - Ano 2019 - Special Edition

ISSN | 2179-7137 | http://periodicos.ufpb.br/ojs2/index.php/ged/index

complement, and possibly extend the earlier pilot results.

As a mixed method, specifically sequential exploratory design, the study made use first of qualitative design in a form an evaluation research method. An evaluation research is an applied research that is designed to assess the implementation of program goals and objectives of demonstration programs. As the primary purpose of sequential exploratory design that quantitative data used to enhance and complement qualitative results. Thus, this study made use of Quantitative descriptive research method was used in the study. According to Best (2006), descriptive research is considered to be the most appropriate in studying the situations that have occurred or existed. It is concerned with the conditions that exist, practices that prevail, beliefs that are held, and processes that are going on, effects that are being felt or trends that are developing.

\section{Product Design}

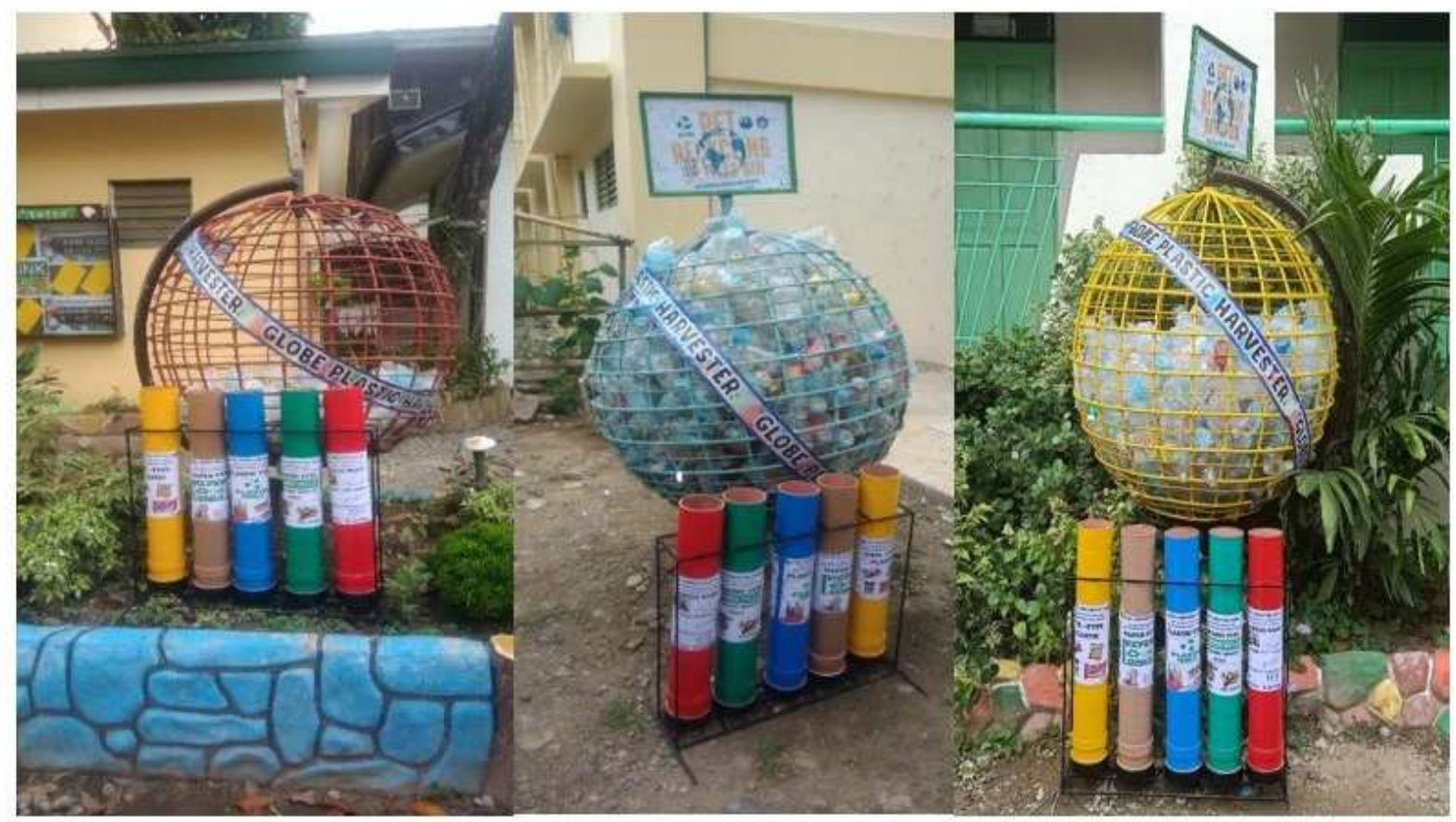

Figure 1 Micro Bins Complimenting Existing Innovation Globe Plastic Bottle Harvester 


\section{S.Gênerg}

Periódico do Núcleo de Estudos e Pesquisas sobre Gênero e Direito Centro de Ciências Jurídicas - Universidade Federal da Paraíba V. 8 - No 07 - Ano 2019 - Special Edition ISSN | 2179-7137 | http://periodicos.ufpb.br/ojs2/index.php/ged/index
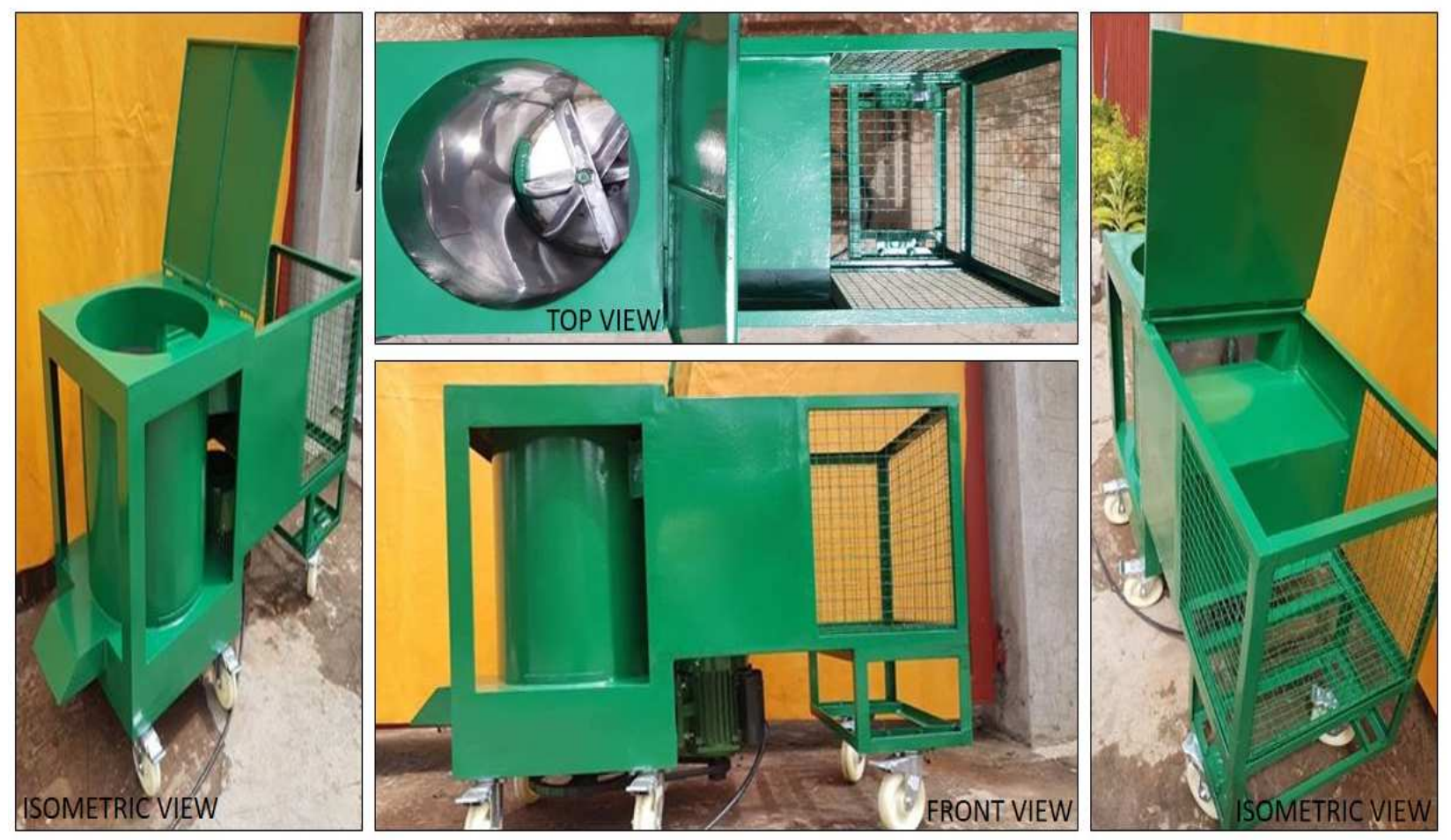

Figure 2 Treatment Facility

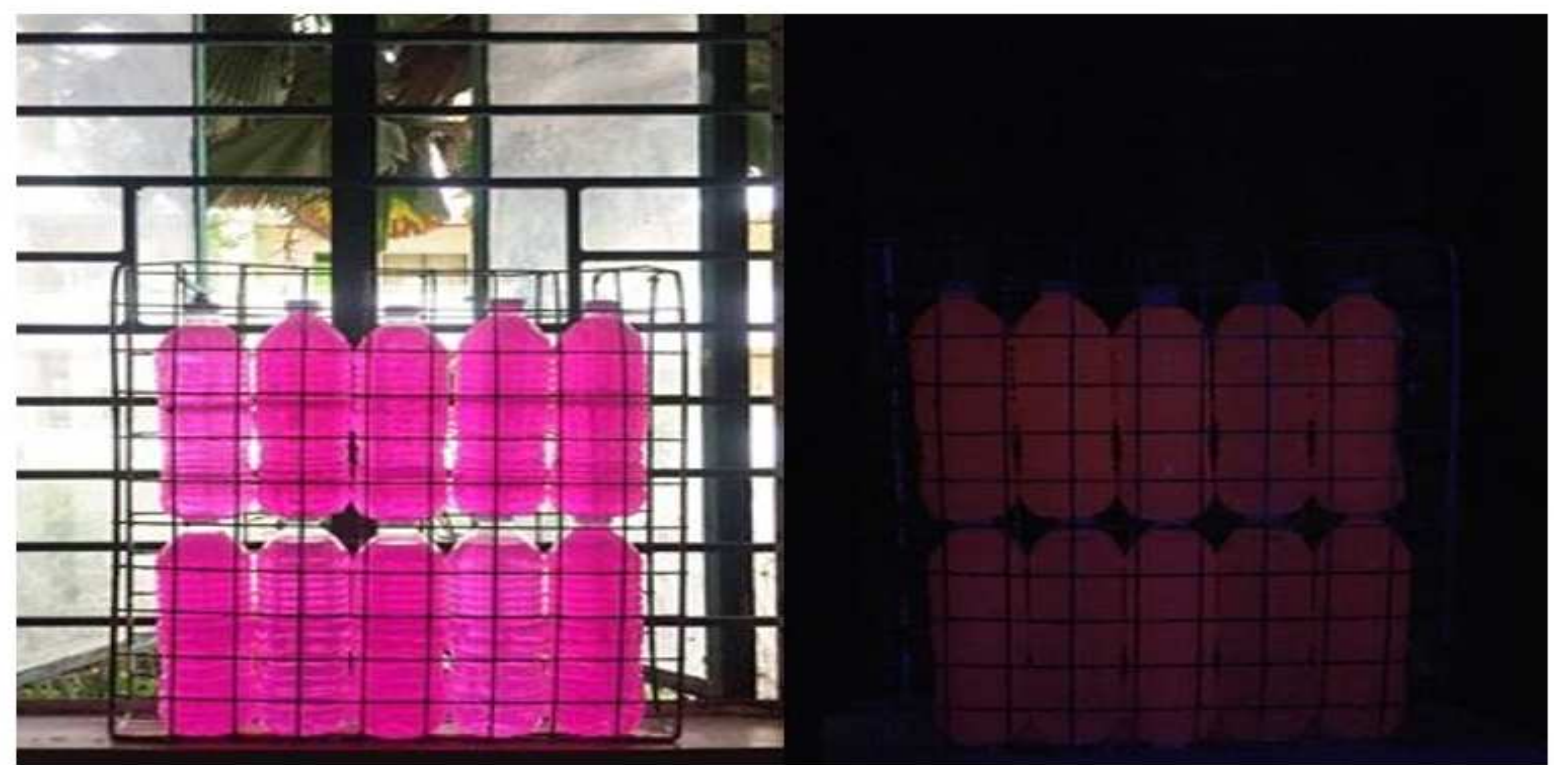

Figure 3 Empty Bottles filled with endothermic compound Infused with Ethylene Glycol. The chemical absorbs heat as temperature goes up, and releases a glow/light as temperature goes down 


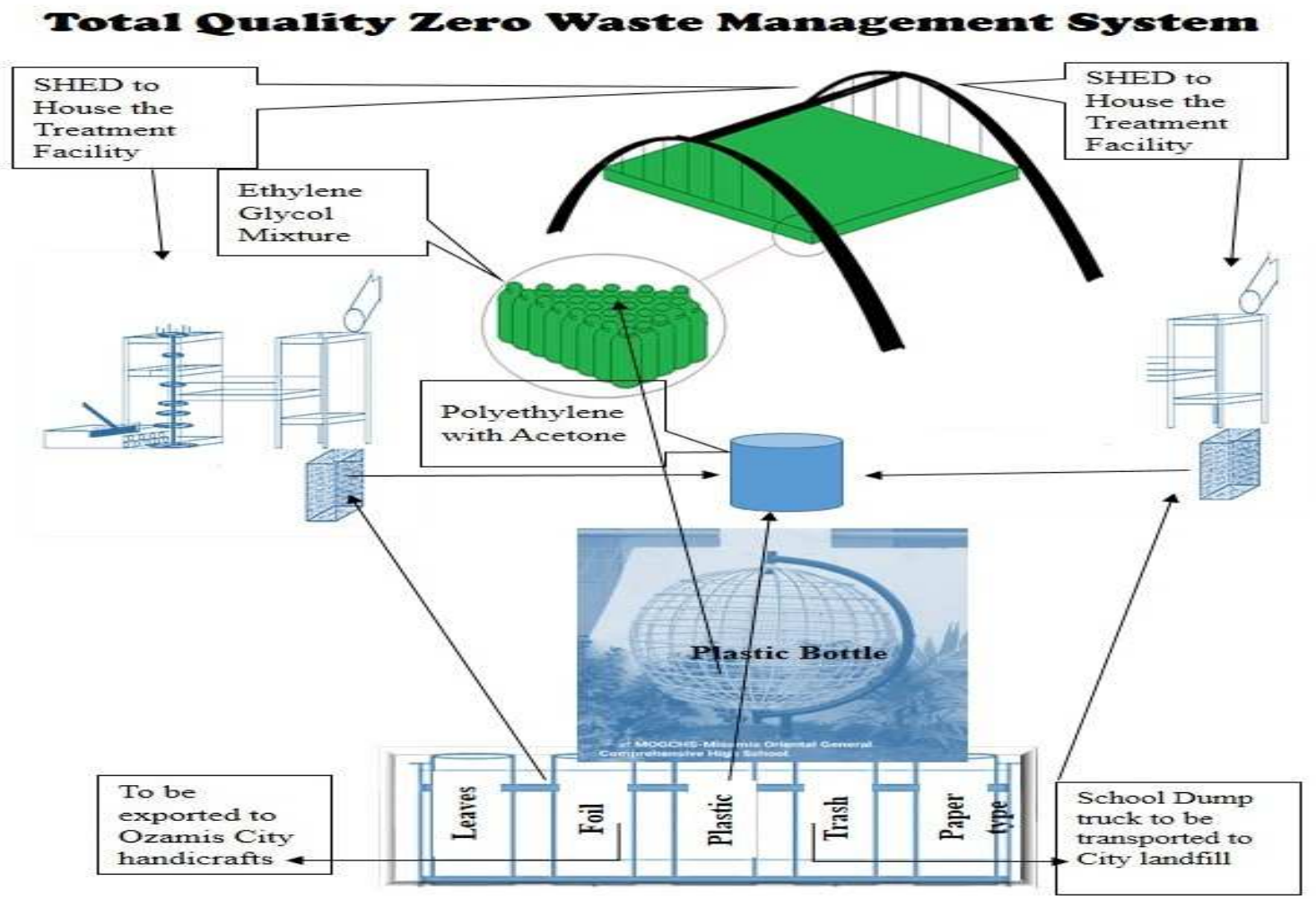

Figure 4 Process Flow

\section{Results and Discussion}

In this part of the paper the results of the data analysis are presented. The data were collected and then processed in response to the problems posed in Action Research Questions of this paper.

Problem 1. What is the degree of application of each Total Quality Management Principles derived from the ISO 9001:2000 standard in the project management of the Total Quality Zero Waste Management System in terms of:

PRINCIPLE 1: Customer focus: Management should understand (and anticipate) the customers' needs and 


\section{Sirainere}

Periódico do Núcleo de Estudos e Pesquisas sobre Gênero e Direito

Centro de Ciências Jurídicas - Universidade Federal da Paraíba

V. 8 - No 07 - Ano 2019 - Special Edition ISSN | 2179-7137 | http://periodicos.ufpb.br/ojs2/index.php/ged/index

requirements, and strive to exceed customer expectations in meeting them.

Customer can be defined as recipient of product and services. Since the research project is about waste management, the recipient of our product and services in basically the city itself. All the waste, if unprocessed goes to Cagayan de Oro City landfill. With 10,000 students and 400 personnel's, the institution itself provides substantial waste to Cagayan de Oro.

In terms of customer-based standards, City Ordinance As what was endorsed by the City Solid Waste Management Board (CSWMB), the 20142024 Solid Waste Management Plan has now been approved with the effect of the Ordinance No. 13130-2016 enacted by the City Council headed by Vice Mayor Raineir Joaquin V. Uy. With this, the city of Cagayan de Oro now has its own 10-year Solid Waste Management Plan. The said plan is in line with Section 166 of Republic Act 9003, the Ecological Solid Waste Management Act of 2000, which stated that the city shall prepare the plan to ensure the efficient management of solid waste

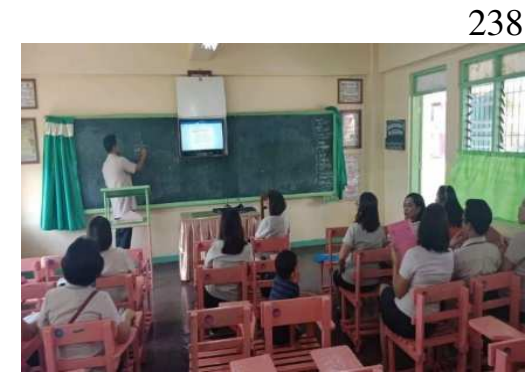

emphasizing on the reuse, recycling and composting program with landfill identification for residual waste. Providing efficient and sustainable system that ensures the protection of the environment and of the public health, importantly the reduction of the amount of generated solid waste which requires disposal via increased source reduction, recycling, composting and utilization of resource recovery technologies and deal with the solid waste with adequate disposal capacity in a fair and environmentally protective system, undeviating with the statutory solid waste hierarchy, are just some of what the Solid Waste Management is aiming for. Furthermore, it is targeting to build community awareness and encourage greater stakeholder's involvement of the need to reduce the generation of waste and disposable practices. In addition the NO SEGREGATION, NO COLLECTION Policy will soon be implemented in Cagayan de Oro. Garbage collectors will 


\section{Sitainero}

Periódico do Núcleo de Estudos e Pesquisas sobre Gênero e Direito Centro de Ciências Jurídicas - Universidade Federal da Paraíba

V. 8 - No 07 - Ano 2019 - Special Edition ISSN | 2179-7137 | http://periodicos.ufpb.br/ojs2/index.php/ged/index

no longer take mixed non-biodegradable and biodegradable waste that is not properly segregated by residences and businesses in the city. The City Local Environment and Natural Resources (CLENRO) will start their campaign on all barangays this January, and will officially enforce the "no segregation, no collection policy on July 1, 2019.

Thus, this research, is in compliance to current customer-based standards demands of the city government of Cagayan de Oro City. This research aims not only to satisfy the needs and requirement of the local government in terms of segregation, but also to enhance it. These researches aims to process solid waste so that the only type of waste that goes to the local landfill were residuals. The rest of the waste were recycled, processed and made useful.

\section{PRINCIPLE 2 Leadership:} Management should establish unity of purpose and direction, and create and maintain an environment in which everyone can participate in achieving the organization's objectives
To start with 239 organization was one of the most difficult part of the project. It was very difficult to recruit researchers who would like to participate in the endeavor. But looking for a researcher to participate is just one concern. We also have to find the right person, for the right topic. However, through referrals and recommendations we were able to gather and organize the research project.

Leadership requires leverage. Leverage means motivation. Thus theory of motivation can be used. One salient, feature that basically initiated the project was the concept of promotion and requirement. This was considered personal purpose, personal direction from the researcher who joined the research. Aspiring Master Teachers need Action Research for promotion, and Master Teachers were required to have an action research. This action of the Department of Education has been a great help for ensuring participation, in a form of motivation. It has facilitated immensely in creating a research environment in the bureau. However, it was not consequential. We encountered rejections and promises 


\section{Sireinero}

Periódico do Núcleo de Estudos e Pesquisas sobre Gênero e Direito Centro de Ciências Jurídicas - Universidade Federal da Paraíba V. 8 - No 07 - Ano 2019 - Special Edition ISSN | 2179-7137 | http://periodicos.ufpb.br/ojs2/index.php/ged/index

but with no participation. However, we were able to find teachers who were willing to participate, with this we conducted a meeting.

In terms of motivation the promotion for aspiring Master Teachers need action research, this will give them an edge during the ranking. Master Teachers are also required to have an action research. This are considered perhaps hygiene factors, in a theoretical perspective, in reference to Herzberg's Two-Factor Theory of Motivation.

\section{According to Prachi (2015)}

Hygiene factors are those job factors which are essential for existence of motivation at workplace. These do not lead to positive satisfaction but if these factors are absent it leads to dissatisfaction. In other words, hygiene factors are those factors which when adequate/reasonable in a job. It pacify the employees and do not make them dissatisfied. These factors are extrinsic to work. This includes Pay - The pay or salary structure is appropriate and reasonable. The salary is equal and competitive to those in the same industry. Hygiene factors includes company and administrative policies, Fringe benefits,
Physical Working conditions, Status, Interpersonal relations and Job Security.

On the other hand there are Motivational factors. According to Herzberg, the hygiene factors cannot be regarded as motivators. The motivational factors yield positive satisfaction. These factors are inherent to work. These factors motivate the employees for a superior performance. These factors are called satisfiers. These are factors involved in performing the job. Employees find these factors intrinsically rewarding. The motivators symbolized the psychological needs that were perceived as an additional benefit. Motivational factors include Recognition, Sense of achievement, Growth and promotional opportunities, Responsibility, Meaningfulness of the work.

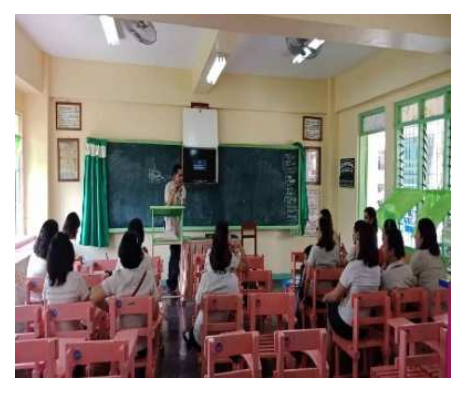

Since the Department of Education has already provided the Hygiene factors, as head researcher, the focus now is on motivational factors. Responsibility and Meaningfulness of the 


\section{S5ireinere}

Periódico do Núcleo de Estudos e Pesquisas sobre Gênero e Direito Centro de Ciências Jurídicas - Universidade Federal da Paraíba V. 8 - $\mathrm{N}^{\circ} 07$ - Ano 2019 - Special Edition ISSN | 2179-7137 | http://periodicos.ufpb.br/ojs2/index.php/ged/index

work were key components of motivation for the realization of the project. A calling to contribute and to make a difference in this world was highlighted during meetings. The idea, that the world might be influenced by our research is in itself a motivation that brings out passion to work from the researchers. The idea, that the world will be different, and it started in MOGCHS, and them being part of it, is essentially as important as other motivational schemes and incentives. In addition, someone helping them with their action research is something we consider an incentive. They participated because someone will help them.

The challenge was letting their purpose evolve from personal purpose of promotion or job requirement, to something bigger than themselves. This demands "leadership", not just concepts or theories of motivation. Leadership is a critical word. In theoretical perspective of leadership, leadership trait theory believe that people inherit certain qualities and trait that make them better suited to leadership. Reinforced by Thomas Carlyle who stated that to suggest that leaders do not enter the world with extraordinary endowment is to imply that people enter the world with equal abilities and equal talents. In contrast a professor in Illinois states that that it is $30 / 70$ split, $30 \%$ of leadership qualities are genetic, $70 \%$ are due to the demands of environment. And Peter Brucker stated that plans are only good intentions unless they immediately degenerate into hard work. Despite this debate whether leaders were born or made, the demand for leadership was inevitable.

With this debate, whether leader were born or made, how to lead, what motivates are open ended questions. But the evolution of purpose, which is selfdirected such as promotion can only be redesigned to a purpose which is not just direct to self, but also to others. That itself, is another set of leadership framework which is metaphysical, or perhaps spiritual. Simple concept of leadership that is selfish not just of the leader but also of the people against an anti-thesis of a simple concept of leadership that is selfless not just of the leader but also of the people is in itself an intriguing paper. However, in this research it was highlighted that the purpose, which is self-directed such as promotion is invited and challenged to a purpose which is not 


\section{Direite}

Periódico do Núcleo de Estudos e Pesquisas sobre Gênero e Direito

Centro de Ciências Jurídicas - Universidade Federal da Paraíba

V. 8 - No 07 - Ano 2019 - Special Edition ISSN | 2179-7137 | http://periodicos.ufpb.br/ojs2/index.php/ged/index

just direct to self, but also to others. It was highlighted during every meeting. It was reiterated in every communication.

\section{PRINCIPLE 3 Involvement of}

people: Management should involve all people at all levels so that they willingly contribute their abilities in achieving the organization's goals;

Vijayavel J. et al, 2014 in the International Journal of Pharmaceutical Sciences and Business Management, Vol.2 Issue. 9, September- 2014, pg. 36-41 entitled "Principle of Total Quality Management (TQM) governing automotive industries with reference to skill enhancement and addition capacity. On page 40 the author said that TQM places a great deal of responsibility on all workers. If employees are to identify and correct quality problems, they need proper training. Thus, there was a need to launch the project, and involve the teachers and the

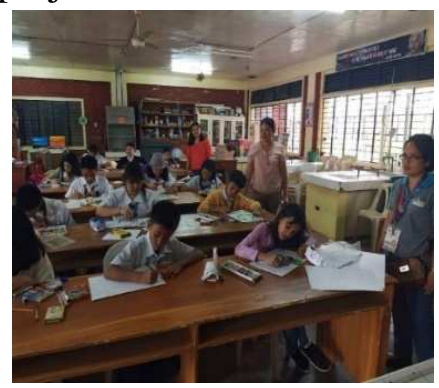

students about

Total Quality

Zero Waste

Management

System.

The author (Vijayavel J. et al, 2014) further adds that the impact of human resources in the organization depends on the kind of empowerment given to them. In TQM, the role of employees is very different from what it was in traditional systems. Similar to our study, researcher were empowered to make decisions relative to quality in the production process and information dissemination. They are considered a vital element of the effort to achieve high quality. Their contributions are highly valued, and their suggestions are implemented. In order to perform this function, employees are given continual and extensive training in quality measurement tools. In light of our research, during the launching, students were informed of the processes of micro segregation and processing. What to do and where to go.

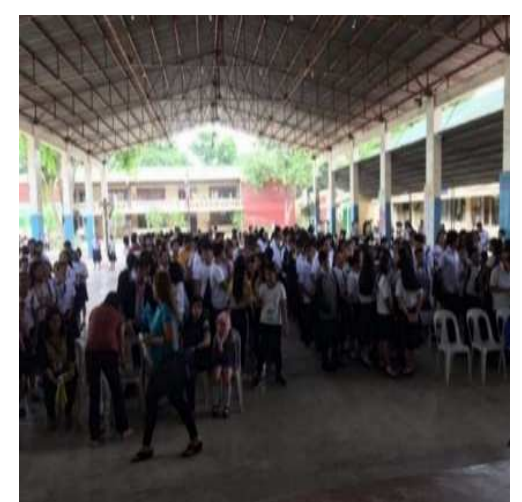




\section{Sônerere}

Periódico do Núcleo de Estudos e Pesquisas sobre Gênero e Direito

Centro de Ciências Jurídicas - Universidade Federal da Paraíba

V. 8 - No 07 - Ano 2019 - Special Edition ISSN | 2179-7137 | http://periodicos.ufpb.br/ojs2/index.php/ged/index

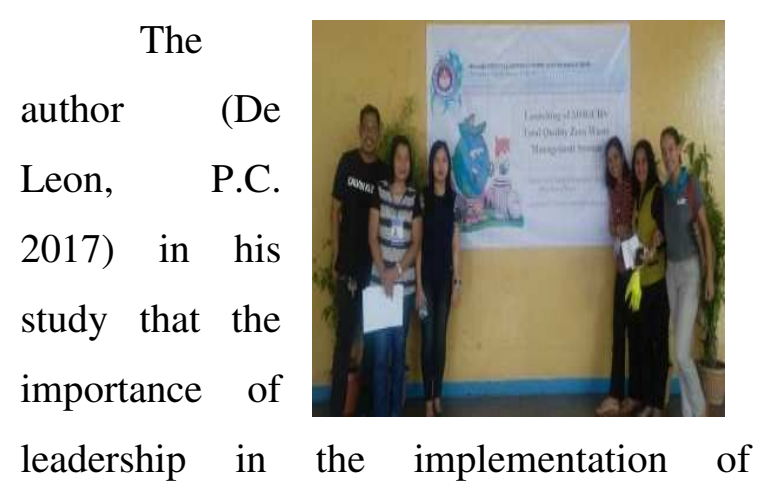

TQM/ISO 9001. He cited an example where local chief executives and department heads were the drivers of TQM/ISO 9001. Their desire to accelerate the development of frontline service standards and achieve

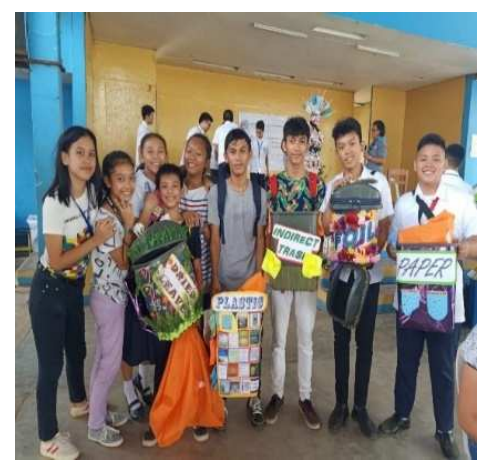

customer

satisfaction

without

sacrificing

regulatory

requirements

motivated

them to adopt

TQM/ISO 9001. The author set the framework, perhaps the step by step procedure on how things should be. The author sets the technical aspects on how the people are involved in the development of frontline servicing which is the people. Each researcher contributed to ideas on how students will be educated about the program and widespread dissemination of

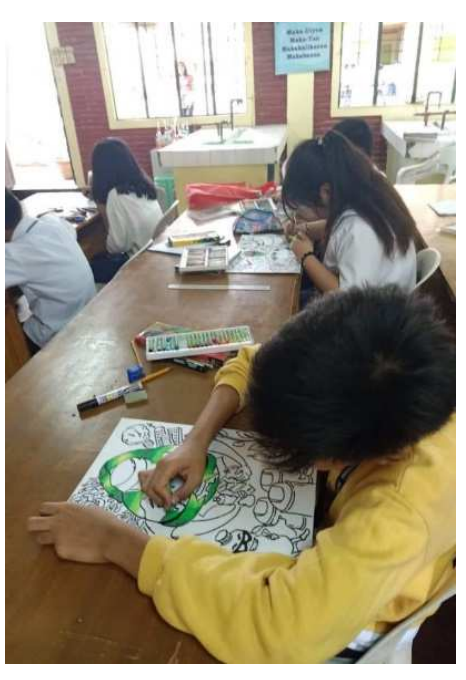

243

information, technical knowledge on the operation of the system.

In

addition, it is perhaps hard to consider the application of

Total Quality Management Principles considering diverse culture and practices. Crucial principles on Total Quality Management is principle number 2, Leadership: Management should establish unity of purpose and direction, and create and maintain an environment in which everyone can participate in achieving the organization's objectives. And principle 3 Involvement of people: Management should involve all people at all levels so that they willingly contribute their abilities in achieving the organization's goals. Because of the information drive, launching of the project, all levels were involved, from teachers to students. There is a great link that connects the organizational goal and the people involved, and that is leadership. The 


\section{Sirainere}

Periódico do Núcleo de Estudos e Pesquisas sobre Gênero e Direito

Centro de Ciências Jurídicas - Universidade Federal da Paraíba

V. 8 - No 07 - Ano 2019 - Special Edition ISSN | 2179-7137 | http://periodicos.ufpb.br/ojs2/index.php/ged/index

direction of the organization and how it is communicated to all requires leadership.

Both principles presuppose that the leader has the competence to establish unity of purpose and direction, at the same time have the capacity to achieve the involvement of people. The literature underscores diverse culture and practices, which make the movement of the leader together with the people, is not as easy as said and done.

The leader may have the capacity to frame a purpose and direction that is united. The leader may have control of both stimulus; hygiene and motivators as stated in Herzberg two factor theory. The leader can redesign the direction of the stimulus from not only self but to others as well, highlighting concepts of responsibility and meaningfulness. But at the end of it all, the movement of the organization or program is not solely dependent to the leader alone, but of the involvement of the people, which according to (Vijayavel J. et al, 2014) is diverse. Answering that diversity seems like a dead end or a great adversity. But fundamentally what a leader can do is to provide an environment which the people, despite the diversity are able to participate in achieving organizational goals. Thus, with the help of 25 researchers we were able to launch the program. The activity was very successful. In fact, though one of the research which was not included in the funding, but was completed in statistical and data analysis stage found out that the post-awareness was significantly greater than the pre-awareness on segregation and the effects to the environment. This means that after the launching of the program, the post-awareness of students significantly increased from their pre-awareness before the program was launched (Orapa et al, 2019)

\section{Principle 4 Process approach:} Management should recognize that an objective is achieved more efficiently when activities and associated resources are managed together as a process;

The next principle In Total Quality management is process approach. Management should recognize that an objective is achieved more efficiently when activities and associated resources are managed together as a process. This process approach is not as simple as stating that the operations in the organization 


\section{S5ireinere}

Periódico do Núcleo de Estudos e Pesquisas sobre Gênero e Direito Centro de Ciências Jurídicas - Universidade Federal da Paraíba V. 8 - $\mathrm{N}^{\circ} 07$ - Ano 2019 - Special Edition ISSN | 2179-7137 | http://periodicos.ufpb.br/ojs2/index.php/ged/index

undergo a process. It has to go through PDCA Plan, Do, Check and Act.

To elucidate further according to International Organization for Standardization BIBC II, Chemin de Blandonnet 8 , CP 401, 1214 Vernier, Geneva, Switzerland in a paper entitled THE PROCESS APPROACH IN ISO 9001:2015 that a process is a set of interrelated or interacting activities that use inputs to deliver an intended re sult. The process approach includes establishing the organization's processes to operate as an integrated and complete system. One, the management system integrates processes and measures to meet objectives. Two, processes define interrelated activities and checks, to deliver intended outputs. Three, detailed planning and controls can be defined and documented as needed, depending on the organization's context. These three concepts together form an integral part of the ISO 9001:2015 standard. Risks that may impact on objectives and results must be addressed by the management system. Risk-based thinking is used throughout the process approach to: One, decide how risk (positive or negative) is addressed in establishing the processes to improve process outputs and prevent undesirable results. Two, define the extent of process planning and controls needed (based on risk). Three, improve the effectiveness of the quality management system. Four, maintain and manage a system that inherently addresses risk and meets objectives. In page two of the paper, ISO came up with PDCA, it is a tool that can be used to manage processes and systems. PDCA stands for: P Plan: set the objectives of the system and processes to deliver results ("What to do" and "how to do it") D Do: implement and control what was planned $\mathrm{C}$ Check: monitor and measure processes and results against policies, objectives and requirements and report results A Act: take actions to improve the performance of processes.

ISO outlines series of activities that a organization can take using PDCA. In accordance with the requirements of ISO 9001 the following sequence of actions provides examples of how an organization may choose to build and control the processes of its quality management system. Performance can be managed and improved by applying the Plan-Do-Check Act (PDCA) cycle. This applies equally to 
the system as a whole, to individual

processes and to operational activities.

\section{Plan-Do-Check Act (PDCA) ANALYSIS}

\begin{tabular}{|c|c|c|}
\hline \multicolumn{3}{|c|}{ PLAN } \\
\hline $\begin{array}{l}\text { Define the } \\
\text { context of the } \\
\text { organization }\end{array}$ & $\begin{array}{l}\text { The organization should } \\
\text { identify its responsibilities, the } \\
\text { relevant interested parties and } \\
\text { their relevant requirements, needs } \\
\text { and expectations to define the } \\
\text { organization's intended purpose. }\end{array}$ & $\begin{array}{l}\text { Region X Division of } \\
\text { Misamis Oriental MOGCHS } \\
\text { Research participants and } \\
\text { their action research under Total } \\
\text { Quality Zero Waste Management } \\
\text { Systems }\end{array}$ \\
\hline $\begin{array}{l}\text { Define the } \\
\text { scope, objectives } \\
\text { and policies of the } \\
\text { organization }\end{array}$ & $\begin{array}{l}\text { Based on the analysis of } \\
\text { the requirements, needs and } \\
\text { expectations establish the scope, } \\
\text { objectives and policies that are } \\
\text { relevant for the organization's } \\
\text { quality management system }\end{array}$ & $\begin{array}{l}\text { Action Researches under } \\
\text { Total Quality Zero Waste } \\
\text { Management Systems }\end{array}$ \\
\hline $\begin{array}{l}\text { Determine } \\
\text { the processes in the } \\
\text { organization }\end{array}$ & $\begin{array}{l}\text { Determine the processes } \\
\text { needed to meet the objectives and } \\
\text { policies and to produce the } \\
\text { intended outputs. }\end{array}$ & Figure 4 \\
\hline $\begin{array}{l}\text { Determine } \\
\text { the sequence of the } \\
\text { processes }\end{array}$ & $\begin{array}{l}\text { Determine how the } \\
\text { processes flow in sequence and } \\
\text { interaction. }\end{array}$ & Figure 4 \\
\hline \begin{tabular}{l}
\multicolumn{1}{c}{ Define } \\
people or remits \\
who take process \\
ownership and \\
accountability
\end{tabular} & $\begin{array}{l}\text { Assign responsibility and } \\
\text { authority for each process }\end{array}$ & $\begin{array}{l}\text { Researchers under Total } \\
\text { Quality Zero Waste Management } \\
\text { System }\end{array}$ \\
\hline
\end{tabular}


Periódico do Núcleo de Estudos e Pesquisas sobre Gênero e Direito Centro de Ciências Jurídicas - Universidade Federal da Paraíba

V. 8 - No 07 - Ano 2019 - Special Edition ISSN | 2179-7137 | http://periodicos.ufpb.br/ojs2/index.php/ged/index

\begin{tabular}{|c|c|c|}
\hline $\begin{array}{l}\text { Define the } \\
\text { need for } \\
\text { documented } \\
\text { information }\end{array}$ & $\begin{array}{l}\text { Determine those processes } \\
\text { that need to be formally defined } \\
\text { and how they are to be } \\
\text { documented }\end{array}$ & $\begin{array}{l}\text { Documented and } \\
\text { submitted Action Research of } \\
\text { each Research Group under Total } \\
\text { Quality Zero Waste Management } \\
\text { System }\end{array}$ \\
\hline $\begin{array}{l}\text { Define the } \\
\text { interfaces, risks and } \\
\text { activities within the } \\
\text { process }\end{array}$ & $\begin{array}{l}\text { Determine the activities } \\
\text { needed to achieve the intended } \\
\text { outputs of the process and risks of } \\
\text { unintended outputs. }\end{array}$ & $\begin{array}{l}\text { Individual Action } \\
\text { Research of each Research } \\
\text { Group under Total Quality Zero } \\
\text { Waste Management System }\end{array}$ \\
\hline $\begin{array}{l}\text { Define the } \\
\text { monitoring and } \\
\text { measurement } \\
\text { requirements }\end{array}$ & $\begin{array}{l}\text { Determine where and how } \\
\text { monitoring and measuring should } \\
\text { be applied. This should be both for } \\
\text { control and improvement of the } \\
\text { processes and the intended process } \\
\text { outputs. Determine the need for } \\
\text { recording results }\end{array}$ & $\begin{array}{l}\text { Quantitative data analysis } \\
\text { of Individual Action Research } \\
\text { under Total Quality Zero Waste } \\
\text { Management System }\end{array}$ \\
\hline \multicolumn{3}{|c|}{ DO } \\
\hline Implement & 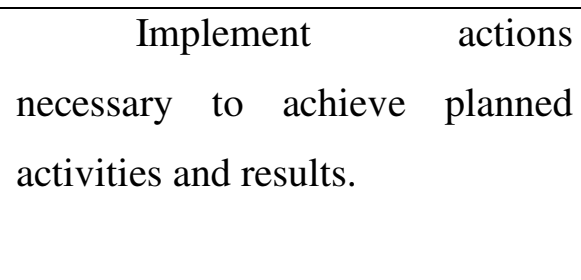 & $\begin{array}{l}\text { Implementation Plan of } \\
\text { Individual Action Research } \\
\text { Under Total Quality Zero Waste } \\
\text { Management System }\end{array}$ \\
\hline $\begin{array}{l}\text { Define the } \\
\text { resources needed }\end{array}$ & $\begin{array}{l}\text { Determine the resources } \\
\text { needed for the effective operation } \\
\text { of each process. }\end{array}$ & $\begin{array}{l}\text { Implementation Plan of } \\
\text { Individual Action Research } \\
\text { under Total Quality Zero Waste } \\
\text { Management System }\end{array}$ \\
\hline \multicolumn{3}{|c|}{ CHECK } \\
\hline
\end{tabular}


Periódico do Núcleo de Estudos e Pesquisas sobre Gênero e Direito Centro de Ciências Jurídicas - Universidade Federal da Paraíba

V. 8 - $\mathrm{N}^{\circ} 07$ - Ano 2019 - Special Edition ISSN | 2179-7137 | http://periodicos.ufpb.br/ojs2/index.php/ged/index

\begin{tabular}{|c|l|l|l|}
\hline $\begin{array}{c}\text { Verify the } \\
\text { process against its } \\
\text { planned objectives }\end{array}$ & $\begin{array}{l}\text { Confirm that the process is } \\
\text { effective and that the } \\
\text { characteristics of the processes are } \\
\text { consistent with the purpose of the } \\
\text { organization. }\end{array}$ & $\begin{array}{l}\text { Quantitative data analysis } \\
\text { of Individual Action Research } \\
\text { under Total Quality Zero Waste } \\
\text { Management System }\end{array}$ \\
\hline Improvement & $\begin{array}{l}\text { Change the processes to } \\
\text { ensure that they continue to } \\
\text { deliver the intended outputs }\end{array}$ & $\begin{array}{l}\text { Quantitative data analysis } \\
\text { and evaluation of Individual } \\
\text { Action Research under Total } \\
\text { Quality Zero Waste Management } \\
\text { System }\end{array}$ \\
\hline
\end{tabular}

Principle 5 Systems approach: Management should recognize that identifying and understanding interrelated processes, and managing them as a system, is more efficient and effective in achieving the organization's objectives;

Another principle in Total Quality Management is Systems Approach Management should recognize that identifying and understanding interrelated processes, and managing them as a system, is more efficient and effective in achieving the organization's objectives. Chikere and Nwoka in an article International Journal of Scientific and Research Publications, Volume 5, Issue 9, September 2015 cited
Flood and Jackson who defined a system as a complex and highly interlinked network of parts exhibiting synergistic propertiesthe whole is greater than the sum of its parts. It is a collection of interrelated parts acting together to achieve some goal which exists in the environment. Also, system is defined as a set of objects together with relationships between the objects and between their attributes related to each other and to the environment so as to create or form a whole. With respect to management, system simply refers to a set of different independent parts working together in interrelated manner to accomplish a whole. It is with this essence that synergism appears. For instance, an 


\section{Sireinero}

Periódico do Núcleo de Estudos e Pesquisas sobre Gênero e Direito Centro de Ciências Jurídicas - Universidade Federal da Paraíba V. 8 - No 07 - Ano 2019 - Special Edition ISSN | 2179-7137 | http://periodicos.ufpb.br/ojs2/index.php/ged/index

organization is formed by different departments, sections, and units composed of individuals and groups which are independent, but working together to achieve a common goal with the aim of turning organizational vision into reality.

In relation to the literature stated above, this research Total Quality Zero Waste Management System follows a system approach. Each different research is a part of the whole which is this research. Each research is independent from other research. however there is a consequential connection between each researches to the other. The results of the research of each researcher influence the other research. By

If there is no improvement in awareness of students, it would basically mean there is no improvement in behaviors in terms of segregation. Thus, the facility that process each waste specifically, might not function in its optimal performance, because it will have back logs such as resegregation, clearing procedures, before it can undergo full treatment.

Originally, there were 9 different researches that was managed by this research, however due to funding, not all were able push through. However, those independent it means, a research under the Total Quality Zero Waste Management System, can or should operate alone. It has its own objectives and methodologies. However, the results of one research may influence the other research. For example the research on Awareness of students in MOGCHS on segregation, and the effect of Micro Segregation is successful. By consequence, the application of micro segregation as it is processed in the different waste treatment facility is also a success. But if not, then it would be affected. It can be elucidated in this scenario. Since there

necessary actions, despite the absence of funding were still accomplished, within the limits of financial capacity and its inevitability.

Chikere and Nwoka (2015) in page 4 of the article The Systems Theory of Management in Modern Day Organizations also cites Gibson et al who stated that, the concept of the organization as a system that is related to a larger system, introduces the importance of feedback. Organizations depend on the environment not only for its inputs, but for 


\section{Sirieite}

Periódico do Núcleo de Estudos e Pesquisas sobre Gênero e Direito Centro de Ciências Jurídicas - Universidade Federal da Paraíba V. 8 - $\mathrm{N}^{\circ} 07$ - Ano 2019 - Special Edition ISSN | 2179-7137 | http://periodicos.ufpb.br/ojs2/index.php/ged/index the acceptance of outputs. Consequently, they must develop means for adjusting to environmental demands. Simply put, feedback refers to information that reflects the outcomes of an act or series of acts by an individual, group or organization.

Feedback is important in system approach; each research has its feedback mechanism that evaluates the innovation. And there is also a feedback mechanism that evaluates as a whole the application of Total Quality Management Principles as Implemented by the head researcher.

Principle 6 Continual improvement: Management should aim at steady, incremental improvement in the organization's overall performance as a permanent objective;

(Cahill 2015) in an article entitled In ISO 9001:2015 Continual Improvement, written Kelmac International USA stated that the specific actions required for Continual Improvement (CI), is on the risk register as a key input to any preventive action. Cahill, an ISO consultant and auditor have outlined in a previous article the process of risk analysis. Regulatory and client sensitive issues naturally receive more focus. For Continual Improvement, opportunities are lost when each of the lower risks items are not each considered. Very often other opportunities are also lost because the top management does not engage with the little issues that staff are having and the simple savings that can be made.

The author clarified the concept by narrating a situation. It was once asked to support a production process in a nonregulated environment and the planner for the process regarding change control that the planner had to execute. The planner had executed multiple change controls during the busy periods for several years, and was very experienced and knowledgeable. While discussing the change control, the author observed the pile of manufacturing orders in their hands. The planner began to handwrite the change control onto each manufacturing order. The paperwork was the first batch, out of hundreds for that busy period. When the auditor queried the handwritten changes and the extent of the work that was involved, the planner expressed the frustration that the planner frequently experienced every day when 


\section{Sitainero}

Periódico do Núcleo de Estudos e Pesquisas sobre Gênero e Direito Centro de Ciências Jurídicas - Universidade Federal da Paraíba V. 8 - No 07 - Ano 2019 - Special Edition ISSN | 2179-7137 | http://periodicos.ufpb.br/ojs2/index.php/ged/index

these changes occurred. Cahill asked the planner had anyone ever looked at this issue as it was clear that this could be simplified. Two days later the planner introduced a simple (self-adhesive) Postal Label, where the planner typed one change and then printed off multiple copies of the same change and applied the planner to the applicable manufacturing orders. This rather obvious solution had a big impact in the daily life of the planner. It was an easy inexpensive solution, quick to implement, and directly made the planners work environment easier.

In this case, the head research should stand back and look at our own organization, and look at Continual Improvement from the bottom up as much as from the top down. By approaching it from the bottom up, the application of the researches can be directly improved. They see direct benefits and are more willing to get involved in other solutions.

Based on the given literature, it is more benefit to have a bottom up communication system, other than top to bottom, feedback from front liners in this team research is important. The key concept for continual improvement is not just the idea proclaimed by 251 management or leader to improve continuously. It is not enough for top management to inspire bottom employees to perform, work and act. It is not enough that the leader can lead. Feedback is essential, but not always from top to bottom, Solution from bottom to top is more relevant than solutions from top to bottom.

In a common setting, after project implementation. The leader talks about the success or the failure of the project, setbacks, lapses and areas of improvement. Things to be improved, and how to improve it. The leader can even inspire the worker/employees to work better. But based on the stated literature from an ISO consultant and auditor Cahill (2015). It is not always that the top management has the say for continual improvement. Bottom employees, workers and in this case researchers under the Total Quality Zero Waste Management System can provide significant inputs for continual improvement. Different researchers are front liners. They have firsthand experience with the project. Their experiences are real and practical. Thus, 


\section{Sichiere}

Periódico do Núcleo de Estudos e Pesquisas sobre Gênero e Direito Centro de Ciências Jurídicas - Universidade Federal da Paraíba V. 8 - No 07 - Ano 2019 - Special Edition ISSN | 2179-7137 | http://periodicos.ufpb.br/ojs2/index.php/ged/index

they may give real and practical solution for continuous and sustainable improvement. Which the head researcher in this organization should always consider, when the principle of Total Quality Management, continual improvements comes to mind.

In an applied perspective, most researches under Total Quality Zero Waste Management System has a bottom up feedback/evaluation mechanism. Specifically, all the waste treatment facilities as well as the plastic bottle harvester and Micro-bins were evaluated by the users. The results were quantified and went through statistical procedure. Qualitative data were also gathered from the users, for areas of improvement of the plastic bottle harvester, micro bins and different waste treatment facility.

PRINCIPLE 7 Factual approach to decision making: Management should base its decisions solely on the analysis of data and information;

In a paper of Marta Kucerova M and Skurkova K(2013) from research papers faculty of materials science and technology in Trnava Slovak University of Technology in Bratislava, Volume 21 entitled Factual Approach in decision making- the prerequisite of Success in Quality Management. In Page one the author states that Application of the factual approach principle in decision making in business practice leads to the implementation of the measurements and collection of the data and information needed to achieve that objective. It ensures that the data and information are sufficiently accurate, reliable and accessible; it leads to the data and information analysis, to the application of decisions and taking actions as a result of logical analysis based on experience and intuition.

In addition on page 4 Marta Kucerova M and Skurkova K(2013) states that in accordance with the principle of factual approach in decision making, the organization has to define, plan and implement the measuring and monitoring activities that are necessary to ensure conformity and improvements. This includes the identification of needs and use of appropriate methods including statistical techniques. An organization has to perform 


\section{S5ireinere}

Periódico do Núcleo de Estudos e Pesquisas sobre Gênero e Direito Centro de Ciências Jurídicas - Universidade Federal da Paraíba V. 8 - $\mathrm{N}^{\circ} 07$ - Ano 2019 - Special Edition ISSN | 2179-7137 | http://periodicos.ufpb.br/ojs2/index.php/ged/index

these activities to make sure that the monitoring and measuring activities necessary to ensure compliance and improvements are defined, planned and applied. The current requirements on QMS also insist on the application of new measurement processes which are rather of systemic than technical character; that means they indicate the state of QMS. The measurement process is extended by the activities of measuring and monitoring which are related to the efficiency of the QMS, performance processes, customer satisfaction, employee and other stakeholder satisfaction, the costs in quality management

In order to achieve the principle of factual approach in decision making implies that effective decisions are based on the analysis of data and information. To meet this principle successfully, it is necessary to perform the following tasks in organization to collect accurate and reliable data from various processes in organization. The organization should use appropriate statistical methods for data collection and analysis, train people to use statistical methods in data collection and analysis, encourage managers to use the analyzed data in decision making, ensure accessibility of the data analysis results for the company employees, as much as possible.

In an applied perspective, this research and each research made use of statistical procedure to evaluate the implementation of the program, the innovation and the facility. Descriptive statistics, percentage, frequency and frequency distribution, mean and standard deviation were used in the study. All of these statistical results are used to evaluate and present the program, and the processes within the program. The statistical results were also used as basis for future improvements. In some cases, immediate but minor augmentation and corrective procedure of the facility, program and processes within the program to ensure quality implementation and delivery of the system.

PRINCIPLE 8 Mutually beneficial supplier relationships: Management should enhance the interdependent relationship with its suppliers for mutual benefit and in creation of value. 


\section{S.s. Direrite}

According to isoTracker Solutions

Ltd. (2019) in an online article entitled Mutually Beneficial Supplier Relationships and Quality Management, that one of the most important aspects of quality management within an organization is developing and maintaining a mutually beneficial relationship with suppliers. It is one of the 8 principles set out by ISO standards, which aims to present organizations with guidelines to enhance quality within the organization according to universal quality management standards. ISO defines the principle of mutually beneficial supplier relationships as follows: "An organization and its suppliers are interdependent, and a mutually beneficial relationship enhances the ability of both to create value."

In addition, the article points out the Primary benefits of Mutually Beneficial Supplier Relationships \& Quality. One, Increased capacity to create value for both suppliers and the organization. Two, Flexibility and faster joint responses to changing market conditions or customer requirements and expectations. And three, Optimized costs and resources across the board.
In order to achieve the principle 7 Steps to Improve Supplier Performance \& Quality Management where indicated in the online article isoTracker Solutions Ltd. (2019) that to ensure a greater level of commitment to quality management within the organization, the following steps can be taken to apply the mutually beneficial supplier relationships principle: 1.Identify and select key suppliers, who should be selected for the value that they add to the organization as well as their approach to the supply chain. 2. Develop supplier relationships that address both short-term advantages with long-term concerns for the organization and ensure a greater level of commitment to quality across the supplier and organization's operations. 3. Develop clear an open communications to ensure that there is a greater level of transparency and accountability among suppliers and the organization. 4. Initiate cooperative development and enhancement of products and processes, to ensure the best level of quality for the organization as well as the supplier. 5. Mutually create a clear understanding of customer needs in regards to the organization, to ensure that suppliers are able to comprehend these needs to 


\section{Sitainero}

Periódico do Núcleo de Estudos e Pesquisas sobre Gênero e Direito Centro de Ciências Jurídicas - Universidade Federal da Paraíba V. 8 - $\mathrm{N}^{\circ} 07$ - Ano 2019 - Special Edition ISSN | 2179-7137 | http://periodicos.ufpb.br/ojs2/index.php/ged/index

deliver the best level of service. 6. Share information and forthcoming goals and targets, so that both the supplier and the organization can work together to achieve these goals. 7. Identify and recognize supplier improvements and achievements, to maintain positive relationships and motivate suppliers to continue to strive for improved quality.

In terms of this research, the supplier are the producers of the different facilities, Globe Plastics Bottle Harvested, Micro-segregation bins, Waste treatment facility for organic (leaves and food scraps) and paper type waste. Communicating the shared value of quality to the suppliers of the facilities, the users of the facilities and the contributors of the project was one of the most challenging endeavor that this research encountered. It was already a challenge imparting and owning that shared value of quality amongst researchers or the organization, much more sharing, communicating, imparting and owning that value to others.

However, this was address with a strategy of a word that is already stated in the principle, which is benefit. Emphasizing and reiterating that the system would benefit everybody; the environment, the surroundings, the administration, the students, the teachers, and basically the world which includes the suppliers/producers of the different facility. Thus, the quality of their efforts, basically comes back to all of us.

The ecological movement across the world to zero waste is in fact a result on how the citizens of $21^{\text {st }}$ century has destroyed the environment, from which destruction of the environment resulted to climate change, flash floods, extreme changes in temperature, and decrease of food supply and demand ratio. Fundamentally, what we do comes back to us. This concept of mutual benefit between people's action and environment, is used as a leverage, or concept for discussion with the supplier, that quality is a value that we all should share, because at the end of it all, the results of our endeavor is for our environment. Our environment will just reciprocate whatever we do to it.

Problem 2. What is the evaluation of the researchers towards application of the (Project manager/Head researcher) of Total Quality Management Principles 
derived from the ISO 9001:2000

standard?

Table 1 evaluation of the researchers towards application of the Project manager/Head researcher of Total Quality Management Principles derived from the ISO 9001:2000 standard

\begin{tabular}{|c|c|c|c|}
\hline Description & Range & Frequency & $\begin{array}{c}\text { Percentage } \\
\text { Distribution }\end{array}$ \\
\hline Very Good & $\begin{array}{c}3.70- \\
4.00\end{array}$ & 10 & $76.92 \%$ \\
\hline Good & $2.80-$ & 3 & $23.08 \%$ \\
\hline Poor & 3.69 & 0 & $0.00 \%$ \\
\hline Very Poor & 2.79 & 0 & $0.00 \%$ \\
\hline
\end{tabular}

Standard Deviation 0.28

The data shows that majority seventy seven percent $77 \%$ of the researchers evaluated head researchers application of principle of total quality management as very good. The over-all rating is also very good
$($ mean $=3.85)$. The standard deviation of 0.28 indicates that the researchers' evaluation of the head researcher's application of principle of total quality management is similar or close to each other. 
The Project Manager/Head researcher of Total Quality Zero Waste Management System followed the following principle

(1) Customer focus: Management should understand (and anticipate) the customers' needs and requirements, and strive to exceed customer expectations in meeting them;

(2) Leadership: Management should establish unity of purpose and direction, and create and maintain an environment in which everyone can participate in achieving the organization's objectives;

(3) Involvement of people: Management should involve all people at all levels so that they willingly contribute their abilities in achieving the organization's goals;

(4) Process approach: Management should recognize that an objective is achieved more efficiently when activities and associated resources are managed together as a process;

(5) Systems approach: Management should recognize that identifying and understanding interrelated processes, and managing them as a system, is more efficient and effective in achieving the organization's objectives;

(6) Continual improvement: Management should aim at steady, incremental improvement in the 
Periódico do Núcleo de Estudos e Pesquisas sobre Gênero e Direito Centro de Ciências Jurídicas - Universidade Federal da Paraíba

V. 8 - No 07 - Ano 2019 - Special Edition ISSN | 2179-7137 | http://periodicos.ufpb.br/ojs2/index.php/ged/index

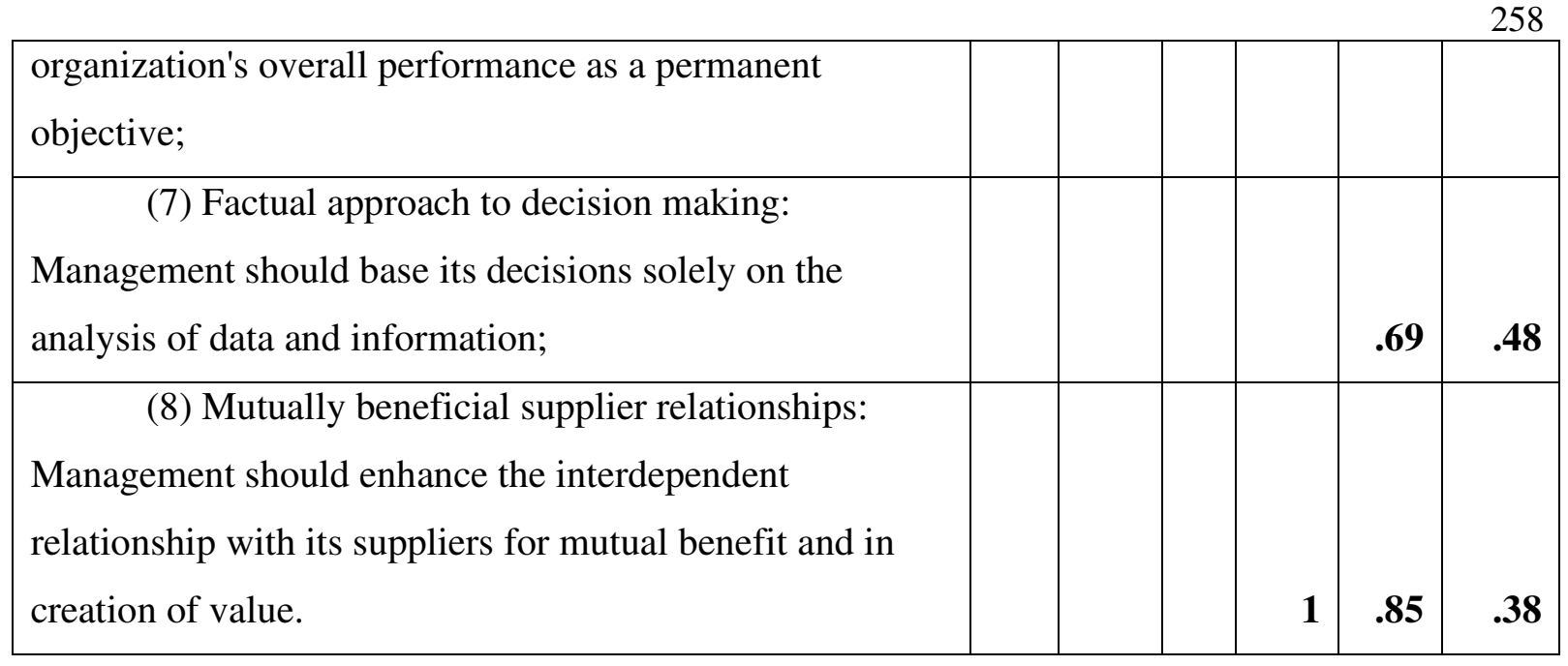




\section{Problem 3. What other significant principles, values, skills that the (Project manager/Head researcher) possess that constituted to the success of the project.}

The qualitative results were enlightening. It basically highlight qualitatively and specifically from each researches perspective on the traits of head researcher that constituted to the success of the research. Competence was a common response from the researchers. Similar responses that the head researcher is highly skilled in research paper writing as well as in statistical procedure. This also includes competence in financial management and control, and leadership. The head researcher made sure that he was able to get the best out of each researcher, but most importantly, making the working experience a positive one. It was also mentioned that the head researcher had good communication skills and people management skills.

Another trait that the researchers indicated is on Commitment. The head researcher valued the need of the school and the community. The project will benefit everybody. Thus is was supported by everybody. It was also mentioned that the head researcher have enthusiasm about research and very supportive towards researchers.

\section{Findings, Recommendation and}

\section{Conclusion}

\section{Findings}

The principles in Total Quality Management was an effective management model as used in project management and delivery, specifically;

Principle 1: Customer focus: Management should understand (and anticipate) the customers' needs and requirements, and strive to exceed customer expectations in meeting them. The research meets and tries to go beyond the standard set by Local Ordinance No. 13130-2016 is in line with Section 166 of Republic Act 9003, the Ecological Solid Waste Management Act of 2000 .

\section{Principle 2 Leadership:} Management should establish unity of purpose and direction, and create and maintain an environment in which everyone can participate in achieving the organization's objectives. This was carried out through weekly meeting every Tuesday of the week, from 1:30 
PM. To 2:30. During this time, purpose, direction and other content that needs to be communicated were delivered.

Principle 3 Involvement of people: Management should involve all people at all levels so that they willingly contribute their abilities in achieving the organization's goals. Students and teachers were involved in the project. They were also oriented on the project and how they can participate and make contribution for the success of the project.

Principle 4 Process approach: Management should recognize that an objective is achieved more efficiently when activities and associated resources are managed together as a process. ISO outlines series of activities that an organization can take using PDCA (PLAN, DO, CHECK and ACT) tool kit. And this was used in the study.

Principle 5 Systems approach: Management should recognize that identifying and understanding interrelated processes, and managing them as a system, is more efficient and effective in achieving the organization's objectives. Total Quality Zero Waste Management System follows a system approach. Each different research is a
260

part of the whole which is this research. Each research is independent from other research, however there is a consequential connection between each researches to the other. The results of the research of each researcher influence the other research.

$$
\text { Principle } 6 \text { Continual }
$$
improvement: Management should aim at steady, incremental improvement in the organization's overall performance as a permanent objective. Total Quality Zero Waste Management System has a bottom up feedback/evaluation mechanism. Specifically, all the waste treatment facilities as well as the plastic bottle harvester and Micro-bins were evaluated by the users.

Principle 7 Factual approach to decision making: Management should base its decisions solely on the analysis of data and information. This research and each research made use of statistical procedure to evaluate the implementation of the program, the innovation and the facility. Descriptive statistics were used in the study. All of this statistical results were used to evaluate and present the program, and the processes within the program. The statistical results were also used as basis 
for future improvements. In some cases, immediate but minor augmentation and corrective procedure of the facility, program and processes within the program to ensure quality implementation and delivery of the system.

Principle 8 Mutually beneficial supplier relationships: Management should enhance the interdependent relationship with its suppliers for mutual benefit and in creation of value. Communicating the shared value of quality to the suppliers of the facilities, the users of the facilities and the contributors of the project was one of the most challenging endeavor that this research encountered. It was already a challenge imparting and owning that shared value of quality amongst researchers, much more sharing, communicating, imparting and owning that value to others.

The data shows that majority seventy seven percent $77 \%$ of the researchers evaluated head researchers application of principle of total quality management as very good. The over-all rating is also very good (mean= 3.85 ). The standard deviation of 0.28 indicates that the researchers' evaluation of the head researcher's application of principle of total quality management is similar or close to each other.

The researchers believed that the traits of head researcher that constituted to the success of the research were competence and commitment. Most researchers said that the head researcher is highly skilled in research paper writing as well as in statistical procedure. This also includes competence in communication, financial management, and leadership. The head researcher made sure that he was able to get the best out of each researcher, but most importantly, making the working experience a positive one. The head researcher is also described as prompt and digital native. In terms of commitment the head researcher valued the need of the school and the community. The project will benefit everybody. Thus is was supported by everybody.

\section{Recommendation}

It is therefore recommended to use Total Quality Management Principles as framework for the development and delivery of a project. It is recommended that each institution, 
private or government, local or national to adopt and implement the Total Quality Zero Waste Management System. Making each institution more responsible for their own waste and exponentially reducing waste that goes to the local landfill. It is also recommended to innovate, aspire for continual improvement. Continual improvement on the specifications of the facilities, models and framework of management.

\section{Conclusion}

Total Quality Zero Waste Management System provides a framework specifically on the process, on the operations, on the facilities and on the principles necessary to manage the process, the operations and the facilities. There are two critical principles in Total Quality Management. One is Leadership. Second is shared value. The leader must be competent and committed. The competencies of a leader highlight the following; content competence, analytic competence, communicative competence and financial competence. In addition to these competencies, a leadership should have the encouraging competence, with attitudes and values worth emulating. Above all the capacity to work with people making the working experience a positive one. The Second critical principle in Total Quality Management is shared value, though it is just a clause in principle number 8 mutually beneficial supplier relationships. Management should enhance the interdependent relationship with its suppliers for mutual benefit and in creation of value. The creation of value, sharing this value challenges the system to evolve to a culture. The organization, the system values quality. Cascading that value of quality from the organization/system to the producers, suppliers, users, basically to the people is challenging a culture to share the value of quality. In view thereof, a competent leader is needed again to share the value of quality, not just to the organization/system but to the people/culture.

\section{References}

Antonio, Lisa , C. (2010) Study on Recyclables Collection Trends and Best Practices in the 
Philippines. Philippine Business for

Environment, Philippines.

Alessandro Anzalone, Ph.D. ISO 9000 and Total Quality. Hillsborough Community College,

Brandon Campus. March 7, 2011 Retrieve $\quad$ May 2019 From:https://etshare.pbworks.com/f/Cha pter $\% 2014 \% 20$ ISO $\% 209000 \% 20$ and $\%$ 20Total\%20Quality.pdf

Besterfield, D.H. et al. (2003). Total Quality Management , 3rd Edition. Columbus, Ohio

and Upper Saddle River, New Jersey: Prentice Hall.

Chikere, Cornell and Nwoka, Jude (2015) The Systems Theory of Management in Modern

Day Organizations - A Study of Aldgate Congress Resort Limited Port Harcourt. Plot 308, Abacha Road, G.R.A. Phase, Port Harcourt. Department of Management, Ignatius Ajuru University of Education, Port Harcourt International Journal of Scientific and Research Publications, Volume 5, Issue 9, September $2015 \quad$ ISSN 2250-3153 www.ijsrp.org
De Leon, P. C. (2017). Sustaining TQM In An ISO 9001:2008 - Certified Philippine LGU:

The Case Of Calapan City.Journal of Management and Development Studies, $6(1), 23-42$

Deming, Edward W. 14 Points for Total Quality Management.

Retrieved May 20, 2017) fromhttp://asq.org/learn-about-

quality/total-quality-

management/overview/deming-

points.html

https://www.mindtools.com/pages/articl e/newSTR_75.htm

Hackman, J. R. (1987). The design of work teams. In J. Lorsch (Ed.), Handbook of organizational behavior (pp. 315-342). New York: Prentice Hall.

International Organization for Standardization ISO 9001:2000 Quality management

systems - RequirementsPublication date : 2000-12 Edition : 3 Technical Committee ISO/TC 176/SC 2 Quality systems ICS : $\quad 03.120 .10$ Quality 
management and quality assurance 03.100.70 Management systems

https://www.iso.org/standard/21823.htm 1

IsoTracker Solutions Ltd. (2019) Mutually Beneficial Supplier Relationships

and Quality Management. PO Box 50490, London W8 9ES, United Kingdom.

https://www.isotracker.com/blog/mutual ly-beneficial-supplier-relationships-andquality-management/

Juran, Joseph (2007) Total Quality Management. Word Press Retrieved May 20, 2019 from

https://totalqualitymanagement.wordpre ss.com/2009/06/07/dr-joseph-juran/

Kucerova, M and Skurkova L. Factual Approach in Decision Making- The prerequisite of

success in Quality Management. Research papers Faculty of Material Science and Technology in Trnava Slovak University in Brastislava 2013, Volume 21, Number 33
Lgen, D. R., Hollenbeck, J. R., Johnson, M., \&Jundt, D. (2005). Teams in organizations:

From input-process-output models to IMOI models. Annual Review of Psychology, 56, 517-543.

Mindtools.com.(2017) Core leadership theories.Retrieved May 2017 from https://www.mindtools.com/pag

es/article/leadership-theories.htm

Porter Michael, Kramer Mark.(2011)

Creating Shared Values. Harvard Business Review.

Retrieved May 2017https://hbr.org/2011/01/the-bigidea-creating-shared-value

Prachi, Juneja (2015). Herzburg Two Factor Theory. Reviewed By Management Study

Guide Content Team. ISO 2001:2015

Certified Education Provider

https://www.managementstudyguide.co m/herzbergs-theory-motivation.htm

Saracanlao Jan Vincent S. (2017)Research Statistics Using Microsoft Excel. Orion's 
Publishing, Cagayan de Oro City, ISBN

978-621-95719-0-6

Steiner, I. D. (1972). Group process and productivity. New York: Academic Press.

Stockburger, David W. (2016) Introductory Statistics: Concepts, Model and Application.

Missouri State University

Study.com (2017) Service Quality. Definition and Dimension. (c) copyright 2003-2017

Study.com.

Vijayavel J. et al (2014) Principle of Total Quality Management (TQM) governing automotive industries with reference to skill enhancement and addition capacityInternational Journal of Pharmaceutical Sciences and Business Management, Vol.2 Issue. 9, September2014, pg. 36-41 entitled “

Virginia Education. Simplification Process system http://www.virginia.edu/processsimplifi cation/resources/All\%20Worksheets.pdf 